\title{
EARLY DISGOVERERS XXXII
}

\section{P. A. TUTKOVSKIY AND THE GLAGIAL THEORY OF LOESS FORMATION}

\author{
By I. J. Smalley \\ (Glacial Soils Project, Department of Civil Engineering, University of Leeds, Leeds LS29JT, \\ England)
}

\begin{abstract}
In I899 P. A. Tutkovskiy published a theory of loess formation which depended on the presence of large continental glaciers. Unfortunately there was no glacial requirement in the theories of Berg and Richthofen and these have survived better than that of Tutkovskiy with the result that the close relationship between glacial action and loess formation is sometimes overlooked.

RÉsumé. P. A. Tutkovskiy et la théorie glaciaire de la formation du loess. En 1899 P. A. Tutkovskiy publiait une théorie de la formation de loess qui impliquait la présence de grands glaciers continentaux. Malheureusement, les théories de Berg et Richthofen n'exigent pas l'existence de glaciers et elles ont mieux survécu que celle de Tutkovskiy. Il en est résulté que l'étroite corrélation entre l'activité glaciaire et la formation de loess est parfois perdue de vue.

Zusammenfassung. P. A. Tutkovskij und die glaziale Theorie der Lössbildung. Im Jahre 1899 veröffentlichte P. A. Tutkovskij eine Theorie der Lössbildung, die auf dem Vorhandensein grosser kontinentaler Gletscher beruhte. Leider enthielten die Theorien von Berg und Richthofen keinerlei glaziale Voraussetzungen; sie fanden jedoch breitere Anerkennung als die von Tutkovskij. Die Folge ist, dass die enge Beziehung zwischen glazialem Geschehen und Lössbildung manchmal übersehen wird.
\end{abstract}

JAMES GEIKIE in The great ice age (Geikie, 1877) makes only the most passing reference (p. 550) to the loess of the Rhine; no other loess is mentioned, and no attempt is made to develop any distinct connections between loess and glacial action. By 1898 , however, the loess had caught Geikie's attention and in that year he published a long two-part article in the Scottish Geographical Magazine on "The tundras and steppes of prehistoric Europe" (Geikie, I 898) and much of this was given up to a discussion on loess and possible mechanisms for its formation, with some considerable emphasis on the role of glaciers. This paper somehow provoked a response from P. A. Tutkovskiy in Kiev and led to Geikie (who was editor of the Scottish Geographical Magazine) preparing a translation of Tutkovskiy's views on loess which he published in 1900 (Tutkovskiy, I900), one year after the major statement of the theory had appeared in Russian. This paper is believed to be the only direct statement of Tutkovskiy's theory in English, and this may possibly help to account for its neglect. It might have gained a wider acceptance in Russia, but it was quickly superseded by Berg's soil-formation theory (first enunciated in I916). The Berg theory became in effect the "official" theory and Tutkovskiy's was considered wrong and irrelevant.

Tutkovskiy was a firm supporter of the Richthofen aeolian hypothesis, but he saw that there were other questions which needed to be answered. "After a careful examination of the several hypotheses which have been advanced in explanation of the origin of löss, I have come to the conclusion that Baron Richthofen's aeolian hypothesis is entirely consistent with the petrographical, stratigraphical, and palaeontological evidence, and with the geographical distribution and the geological age of the normal löss of Europe and North America. There are many questions, however, which seem at first to throw doubt on the applicability of that beautiful hypothesis. Why, for example, is the formation of the great mass of the löss, alike in Europe and North America, connected with the Glacial Period? Why does no löss occur amongst pre-glacial deposits? Why does löss appear only in association with inter-glacial and post-glacial deposits - that is to say, why is it so intimately connected with the retreat of the 
great ice-sheets? How are we to reconcile a continental climate, so essential to the aeolian formation of löss, with the supposed augmented humidity during the melting of the ice? Whence came the wind to produce the löss, and how could dry deserts exist in Europe during the retreat of the ice-sheet and glaciers? Why did the formation of löss come to an end with the close of the Glacial Period? Lastly, why does not löss occur north of a certain limit? To all these questions I have found a suitable reply; my solution of the difficulties is at once scientific, simple and natural."

The central part of the Tutkovskiy theory is a glacial anticyclone of the type proposed some years later by Hobbs (i $943[\mathrm{a}],[\mathrm{b}])$. "By a theoretical analysis of the meteorological conditions of the great ice-sheet of Pleistocene times, I demonstrate that the isobars over the "inland ice" were concentric, and that the gradients were centrifugal, whence resulted an enormous anticyclonic system which induced constant centrifugal winds. These winds would die off in the adjacent regions, but far beyond the southern limits of the ice-sheet. They would thus necessarily partake of the character of föhns, they would have a temperature elevated in proportion to the descent from the high central part of the inland ice towards its much lower periphery, and they would be very dry winds by reason of that dynamical heating. These conditions, it may be remarked, are to some extent realised at present in Arctic and Antarctic regions, being most pronounced where glaciation is most extensive, as in the north of Greenland."

The Scottish Geographical Magazine article gives a brief argument for Tutkovskiy's views and ends with the statement: "Thus the normal löss . . . is as truly a product of the old inland ice as are moraines, osar, erratics, striae, etc. The difference between it and these is simply this, that the latter tell us of a time when the great mer-de-glace was in the heyday of its might and vigour, while the former are the witnesses of its decay and dissolution." After this the study of loess might have been firmly included within the bounds of glaciology but the influence of L. S. Berg began to grow and Russian loess investigations followed the soil-formation theory for the next fifty years.

Berg's theory (1960) is most accessible to non-readers of Russian in the English translation published in 1964 , and this work also gives some access to the ideas of Tutkovskiy via Berg's denunciation of them. A few extracts will illustrate the tone of Berg's comments:

"the entire anticyclonic-foehn wind hypothesis of Tutkovskii is utterly groundless" (p. 108 of the English translation).

"the construction of Tutkovskii is entirely invalid: when the loess was forming, there were not foehns nor easterlies, nor deflation of the moraine bared by the retreating glacier. Nothing remains of the entire foehn-eolian theory of this author" (p. 112).

"In the view of Tutkovskii (1899, p. 283) the moraine which was bared after the retreat of the glacier must have constituted 'an absolute desert' . . . There cannot be any doubt that such pictures are completely divorced from actual fact" (p. Iog).

The suppression of the Tutkovskiy approach was doubly regrettable because it essentially left just the two theories of Berg and Richthofen in contention, and neither of these contained a specifically glacial dimension.

In IgIo Tutkovskiy presented a paper at the International Geological Congress in Stockholm (Tutkovskiy, I9 I 2); it appears to have made little impact. At the same meeting Łoziński (I 9 I 2) also presented a paper; it also received little attention and yet, according to Jahn (I954) this was the first paper properly to express Łoziński's full periglacial conception. In this paper Łoziński discussed the role of wind among the whole set of periglacial agents, and gave his support to the idea of the periglacial origin of loess (see Jahn, I954, p. I 19-20). The views of Łoziński appear to have been in perfect accord with those of Tutkovskiy, in fact Jahn expressly states that Łoziński fully approved the view set forth by Tutkovskiy (1899) concerning the glacial origin of loess. Łoziński is now recognized as one of the major pioneers of peri- 
glacial studies, but it took thirty years for this to come about. In the mid-nineteen sixties the glacial connections of loess deposits began to be appreciated again, and it may be that eventually Tutkovskiy will receive the recognition he deserves.

It is possible that the I9 Io conference paper was the only major publication of Tutkovskiy's ideas in German; it can serve as a further illustration of the fact that scientific theories need several exposures and much promoting before they are accepted. A better exposure in German and English would certainly have given Tutkovskiy a better chance of acceptance. His later works were written in Ukrainian and cannot have been widely read. They were attacked in his usual fashion by Berg: "It is very characteristic of Tutkovskii's attitude that in spite of all objections he continued until the last to reassert his views, although they had been refuted in the literature. He did not even deem it necessary to argue with his opponents, and only replied that 'all the facts confirm overwhelmingly my own theory'. In his textbook (General Agronomy 1927, pp. I59-160), he continues to repeat his old errors ..." (Berg, 1960, p. 108 of the English translation).

From a viewpoint in the late nineteen seventies, and from a glaciological background, it appears that Berg was more or less completely wrong about loess formation and that Tutkovskiy and Łoziński were on the right lines. The soil-formation theory should however be seen in the context of post-Dokuchayev soil science, and it can be argued that it represents a continuation of Dokuchayev's ideas about loess (Lysenko, 1956). Dokuchayev, as the inventor of soil science - one of the major Russian contributions to world science, had, and still has, great influence on Russian investigators. The major weakness of the soil-formation theory was its inability to explain the formation of the predominant silt fraction in loess. This is usually quartz, and while it is relatively easy to explain the silt formation by glacial action, it is more difficult to find a soil formation process to account for it (Smalley, r97 I). The influence of the soil theory appears to be waning now in the Soviet Union and it is possible that a majority of Russian loess investigators now believe in aeolian deposition. The influence of Obruchev has proved critical in promoting the aeolian theory in the Soviet Union and his division of loess into cold and warm varieties (Obruchev, 1948) introduced an important factor into the argument. The warm or desert loess could be seen to form without the need of soil-formation processes. Actually this desert loess theory of Obruchev's, while it was a useful counter to the soil theory, has served to obscure the glacial connections which Tutkovskiy strove to establish. The loess in Soviet Central Asia (particularly in Uzbekistan) which Obruchev observed, has its origin in the glaciated terrain of the Tien Shan mountains. It may pass through parts of the great Turkestan desert before ending up as a loess deposit at the desert fringes, but it starts out with the glaciers of the Tien Shan.

MS. received 21 September 1977

\section{REFERENCES}

Berg, L. S. 1960. Less kak produkt vyvetrivaniya i pochvoobrazovaniya [Loess as a product of weathering and soil formation]. (From Berg, L. S. Klimat $i$ zhizn' [Climate and life]. Tom 3. Moscow, Izdatel'stvo Akademii Nauk SSSR.) [Translation published by Israel Program for Scientific Translations, Jerusalem, 1964.]

Geikie, J. 1877. The great ice age and its relation to the antiquity of man. Second edition. London, Stanford.

Geikie, J. 1898. The tundras and steppes of prehistoric Europe. Scottish Geographical Magazine, Vol. 14, No. 6, p. $281-94$; No. 7 , p. 346-57.

Hobbs, W. H. I 943 [a]. The glacial anticyclone and the continental glaciers of North America. Proceedings of the American Philosophical Society, Vol. 86, No. 3, p. 368-402.

Hobbs, W. H. I943[b]. The glacial anticyclones and the European continental glacier. American fournal of Science, Vol. 241, No. 4, p. 333-36.

Jahn, A. r954. Zasługi Walerego Łozińskiego w dziedzinie badań peryglacjalnych [Walery Loziński’s merits for the advancement of periglacial studies]. Biuletyn Peryglacjalny, Nr. 1, p. 7-18. [English text, p. 1 1 7-24.]

Loziński, W. I912. Die periglaziale Fazies der mechanischen Verwitterung. Compte Rendu de la XI:e Session du Congrès Géologique Internationale (Stockholm 1910). $2^{\mathrm{e}}$ Fasc. Stockholm, P. A. Norstedt \& Söner, p. 1039-53. 
Lysenko, M. P. 1956. V. V. Dokuchayev i lessovaya problema [V. V. Dokuchayev and the loess problem]. Pochvovedeniye, 1956, No. 7, p. $59^{-67}$.

Obruchev, V.A. 1948. Less kak osobyy vid pochvy, yego genezis i zadachi yego izucheniya [Loess as a particular kind of soil, its genesis and the tasks of its investigation]. Byulleten' Kommissii po Izucheniyu Chetvertichnogo Perioda, 1 948 , No. 12, p. 5-1 7 .

Smalley, I. J. I 97 I. 'In-situ' theories of loess formation and the significance of the calcium carbonate content of loess. Earth-Science Reviews, Vol. 7, No. 2, p. 67-85.

Tutkovskiy, P. A. I899. K voprosu o sposobe obrazovaniya lessa [On the problem of loess formation]. Zemlevedeniye, Tom 6, No. 1-2, p. 213-31 1 .

[Tutkovskiy, P. A.] 190o. M. Paul Tutkowski on the origin of loess. Scottish Geographical Magazine, Vol. 16, No. 3, p. $17 \mathrm{I}-74$.

Tutkovskiy, P. A. 1912. Das postglaziale Klima in Europa und Nordamerika, die postglazialen Wüsten und die Lössbildung. Compte Rendu de la XI:e Session du Congrès Géologique International (Stockholm I9Io). I er Fasc. Stockholm, P. A. Norstedt \& Söner, p. 359-69. 